\title{
KAMPANYE KOMUNIKASI KESEHATAN MELALUI MODEL MULTI STEP FLOW COMMUNICATION DALAM MENEKAN ANGKA PERNIKAHAN USIA DINI PADA MASYARAKAT URBAN DI KABUPATEN BANDUNG
}

\author{
Priyo Subekti, Hanny Hafiar, Trie Damayanti, dan FX Ari Agung P \\ Fakultas Ilmu Komunikasi Universitas Padjadjaran \\ Email : hannyhafiar@yahoo.com
}

\begin{abstract}
ABSTRAK Kasus pernikahan usia dini banyak terjadi di berbagai penjuru dunia dengan berbagai latar belakang. Telah menjadi perhatian komunitas internasional mengingat risiko yang timbul akibat pernikahan yang dipaksakan, hubungan seksual pada usia dini, kehamilan pada usia muda, kehamilan bermasalah, persalinan yang mengalami kesulitan, bayi yang terlahir tidak normal dll. Kemiskinan bukanlah satu-satunya factor penting yang berperan dalam pernikahan usia dini.Metode yang digunakan dalam penelitian ini adalah penelitian deskriptif dengan data kualitatif.Tujuan dari penelitian ini adalah: 1) Bagaimana Karakteristik demografi pelaku pernikahan usia dini pada masyarakat urban. 2) Apa faktor-faktor penyebab masyarakat urban melakukan pernikahan dini. 3) Bagaimana gambaran personal determinans pelaku pernikahan usia dini. 4) Bagaimana gambaran tanggapan pelaku pernikahan usia dini terhadap ILM pernikahan dini. 5) Bagaimana gambaran peranan keluarga terhadap pelaku pernikahan dini.Hasil dari penelitian ini: 1) a) Pendidikan SMP dan SMA b) Menikah di Usia 15-20 tahun c)Ekonomi menengah ke bawah, 2. Faktor-faktor penyebab masyarakat urban melakukan pernikahan dini: Dorongan dari orang tua, Alasan agama, tidak ingin melanggar syariat agama, Keyakinan yang tinggi bahwa dengan menikah di usia dini mampu menyejahterakan keluarga (pendidikan anak), Tingkat pengetahuan yang rendah yang menyebabkan ketidaktahuan akan resiko menikah di usia dini, Lingkungan social yang mendorong untuk segera menikah; 3. Pelaku pernikahan usia muda cenderung belum dewasa secara psikologis disebabkan usia masih berada dalam ranah remaja awal, Pengambilan keputusan penting dalam hidup lebih dipengaruhi oleh afeksi; 4, Untuk mengetahui bagaimana gambaran tanggapan pelakupernikahan usia dini terhadap ILM pernikahan dini, Kuantitas terpaan rendah.
\end{abstract}

Kata kunci: kampanye, kesehatan, pernikahan, usia dini, masyarakat urban

\section{HEALTH COMMUNICATIONS CAMPAIGN THROUGH MULTI-STEP MODEL FLOW RATE OF COMMUNICATION IN MARRIAGE PRESSING EARLY AGE COMMUNITY IN URBAN DISTRICT BANDUNG}

\begin{abstract}
Cases of early marriage occurred in many parts of the world with different backgrounds. Has been a concern of the international community in view of the risks arising from a forced marriage, sexual intercourse at an early age, pregnancy at a young age, pregnancy problems, delivery difficulties, babies born anomalous etc. Poverty is not the only important factor that plays a role in early marriage. The method used in this study is a descriptive study with qualitative data. The purpose of this study are: 1) How do demographic characteristics of perpetrators of early marriage in urban society. 2) What are the factors that cause urban communities of early marriage. 3) How do personalized picture actors determinans early marriage. 4) How would the perpetrator responses against early marriage ILM early marriage. 5) How would the role of the family against the perpetrators of early marriage. Results from this study: 1) a) middle and high school education b) Married at Age 15-20 years c) lower middle Economics, 2. Factors leading to early marriages urban society: Encouragement from parents, religious reasons, do not want to violate religious laws, a high belief that by getting married at an early age is able to improve the life of the family (children's education), a low level of knowledge of the risks of ignorance that causes married at an early age, social environment that encourages to get married; 3. The perpetrator wedding a young age tend to be psychologically immature due to age are still in the realm of early adolescence, decisionmaking is important in life is more affected by affection; 4, In order to determine how the image response early marriage to actor ILM early marriage, low exposure quantity.
\end{abstract}

Keyword: champaign, health, communications, marriage pressing early age, urban.

\section{PENDAHULUAN}

Beredarnya iklan layanan masyarakat (ILM) di televisi belakangan ini menuai beraneka ragam opini. ILM tersebut berasal dari bermacam-macam sumber, seperti Lembaga Swadaya Masyarakat (LSM), Badan Usaha Milik Negara (BUMN), pemerintahan (secara terbuka dimainkan dari jajaran para kementerian) hingga partai politik menjelang Pemilihan Umum. Tak diragukan lagi, ILM di televisi dapat menjadi media yang paling efektif untuk mensosialisasikan program BKKBN mengenai Iklan Layanan Masyarakat 2 anak cukup 4 terlalu. Anak adalah seseorang yang terbentuk sejak masa konsepsi sampai akhir masa remaja. Definisi umur anak dalam Undang-undang (UU) Pemilu No.10 tahun 2008 (pasal 19, ayat1) hingga berusia 17 tahun. Sedangkan UU Perkawinan No.1 Tahun 1974 menjelaskan batas usia minimal menikah bagi perempuan 16 tahun dan lelaki 19 tahun. Definisi anak berdasarkan UU No. 23 tahun 2002, adalah seseorang yang belum berusia 18 tahun, termasuk dalam anak yang masih berada dalam kandungan. Pernikahan anak didefinisikan sebagai pernikahan yang terjadi sebelum anak mencapai usia 18 tahun, sebelum anak matang secara fisik, 
fisiologis, dan psikologis untuk bertanggungjawab terhadap pernikahan dan anak yang dihasilkan dari pernikahan tersebut.

Analisis survei penduduk antar sensus (SUPAS) 2005 dari Badan Koordinasi Keluarga Berencana Nasional (BKKBN) didapatkan angka pernikahan di perkotaan lebih rendah dibanding di pedesaan, untuk kelompok umur 15-19 tahun perbedaannya cukup tinggi yaitu 5,28\% di perkotaan dan $11,88 \%$ di pedesaan. Hal ini menunjukkan bahwa wanita usia muda di pedesaan lebih banyak yang melakukan perkawinan pada usia muda. Meskipun pernikahan anak merupakan masalah predominan di negara berkembang, terdapat bukti bahwa kejadian ini juga masih berlangsung di negara maju yang orang tua menyetujui pernikahan anaknya berusia kurang dari 15 tahun.

Dalam UU No. 1 tahun 1974, pasal 7 ayat (1) menyatakan bahwa perkawinan hanya diijinkan jika pihak pria sudah mencapai umur 19 dan pihak wanita sudah mencapai umur 16 tahun, usulan perubahan pada pasal 7 tahun 1974 ayat (1) perkawinan dapat dan dilakukan jika pihak laki-laki dan perempuan berusia minimal 19 tahun, ayat (2) untuk melangsungkan pernikahan masing-masing calon mempelai yang belum mencapai umur 21 tahun, harus mendapat izin kedua orangtua, sesuai dengan kesepakatan pihak Badan Kependudukan dan Keluarga Berencana Nasional (BKKBN) yang telah melakukan kerjasama dengan MOU yang menyatakan bahwa Usia Perkawinan Pertama diijinkan apabila pihak pria mencapai umur 25 tahun dan wanita mencapai umur 20 tahun.

Namun dalam kenyataannya masih banyak kita jumpai perkawinan pada usia muda atau dibawah umur, padahal perkawinan yang sukses membutuhkan kedewasaan tanggung jawab secara fisik maupun mental, untuk bisa mewujudkan harapan yang ideal dalam kehidupan berumah tangga. Peranan orang tua sangat besar artinya bagi anak- anaknya. Mengingat keluarga adalah tempat pertama bagi tumbuh perkembangan anak sejak lahir hingga dewasa, maka pola asuh anak dalam perlu disebarluaskan pada setiap keluarga.

Kertamuda (2009:30) dalam bukunya Konseling Pernikahan Untuk Keluarga Indonesia menyebutkan faktor social ekonomi, latar belakang pendidikan yang tidak memadai dapat menjadi alasan mengapa orang tua menikahkan anak gadisnya di usia muda. Di beberapa daerah pedesaan, kita terkadang menjumpai sekelompok masyarat yang memeliki tradisi menikahkan anaknya di bawah umur. Tradisi menikahkan anak di bawah umur pada keluarga petani pedesaan tentu saja tidak lepas dari rangkaian tatanan kehidupan mereka yang telah mengakar kuat. Mereka sangat memerlukan anggota keluarga penunjang proses pengolahan lahan pertanian, dan satu-satunya alternative yang dapat mereka pilih adalah menikahkan anak-anak mereka kendatipun masih dibawah umur. Keadaan ini tentunya tidak lepas dari kondisi yang membentuk pola kehidupan mereka yang diwarisi secara turun-temurun, yang memandang proses kehidupan itu tidak lebih dari sesuatu yang bersifat rutinitas.
Perkawinan usia muda yang menjadi fenomena sekarang ini pada dasarnya merupakan satu siklus fenomena yang terulang dan tidak hanya terjadi di daerah pedesaan yang notabene dipengaruhi oleh minimnya kesadaran dan pengetahuan namun juga terjadi di wilayah perkotaan yang secara tidak langsung juga dipengaruhi oleh "role model" dari dunia hiburan yang mereka tonton.

Laporan Badan Koordinasi Keluarga Berencana Nasional (BKKBN) pada bulan Juni 2011 saja untuk usia kawin pertama penduduk wanita kurang dari usia 20 tahun di seluruh Jawa Timur mencapai 6.847 orang atau 19,88 persen dari seluruh perkawinan pertama penduduk wanita di semua usia sebesar 34.443 orang. Jumlah tertinggi angka perkawinan pertama penduduk wanita usia yang sama adalah yang terjadi di Kabupaten Malang yakni dengan 887 perempuan atau 29,09 persen dari total pernikahan 3.049. Sementara prosentase tertinggi dibanding seluruh jumlah pernikahan pada usia tersebut di tempatnya adalah Kabupaten Bondowoso sebesar 196 atau 49,75 persen dari total pernikahan 394 orang. ${ }^{1}$

Lebih lanjut, data tersebut mengungkap sampai dengan pada Juni 2011 laporan usia kawin pertama penduduk wanita seluruh JawaTimur usia di bawah 20 tahun mencapai 34.016 orang atau sebesar 19,97 persen dari jumlah laporan seluruh usia kawin pertama penduduk wanita di Jawa Timur sebesar 171.862 orang.

Sebetulnya secara implisit UU Perkawinan 1 Tahun 1974 pada pasal 6 ayat (2) menyebut seseorang yang belum mencapai umur 21 tahun masih dalam kategori anak. Sementara perkawinan di bawah umur adalah perkawinan yang terjadi pria yang belum mencapai usia 19 tahun dan wanita di bawah 16 tahun (pasal 7 ayat 1 ). Anehnya UU tersebut mensahkan apabila mendapat dispensasi dari pengadilan atau pejabat lain yang diminta oleh kedua orang tua pihak pria atau pihak wanita (pasal 7 ayat 2).

Dengan kata lain perkawinan di bawah umur bisa dilegalkan sekalipun terjadi pada usia anak-anak di bawah 18 tahun (pasal 1 ayat 1 UU nomor 23 Tahun 2003 tentang Perlindungan Anak). Dalam arti, negara mengizinkan perkawinan yang melanggar hak asasi anak (UU No. 39/1999 Bagian Kesepuluh tentang Hak Anak pasal $52 \mathrm{~s} / \mathrm{d}$ pasal 66).

Perkawinan pada anak-anak adalah melembagakan tindakan merenggut kebebasan masa anak-anak atau remaja untuk memperoleh haknya. Tepatnya hak dapat hidup, tumbuh, berkembang, dan berpartisipasi, secara optimal sesuai dengan harkat dan martabat kemanusiaan, serta mendapat perlindungan dari kekerasan dan diskriminasi (pasal 1 ayat 2 UU No 23 Tahun 2002).

Dari data SDKI 1997 diketahui bahwa seekitar $52,6 \%$ wanita pernah melakukan perkawinan pertamanya pada kelompok umur 15-19 tahun dengan tingkat pendidikan hanya tamat SD. Sejumlah 5,8 juta remaja pernah menikah pada umur kurang dari 16 tahun dan 25\% diantaranya bahkan menikah

\footnotetext{
1. Diunduh pada tanggal 22 Oktober 2013 : http://fenomenayangterjadidimasyarakat. blogspot.com/2012/03/nikah-dini-sebagai-suatu-degenerasi.html
} 
dibawah usia 14 tahun. Pihak yang sangat merasakan akibatnya adalah remaja putri atau perempuan karena tidak mempunyai kesempatan untuk bersekolah lagi dan harus menjalani perkawinan yang sebenarnya belum siap baginya, baik dari sisi mental maupun kesehatan reproduksinya.

Sikap atas persoalan ini terbagi dalam dua sisi yang berseberangan. Dengan alasan bahwa dengan menikah di usia muda akan menghindari hal-hal yang dilarang baik asas agama maupun sosial di tengah gejolak pergaulan yang semakin "menggila" seperti saat ini. Alasan lain adalah pikiran bahwa dengan menikah muda, mereka akan masih sehat dan aktif berkarya di saat anak-anak mereka tumbuh besar yang membutuhkan biaya untuk keperluan pendidikan dan persoalan lainnya. Meskipun dengan dalih dari pada terjerat dalam pergaulan bebas dan menghindari terjadinya hamil di luar pernikahan.

\section{Model Komunikasi Banyak Tahap (Multi Step Flow of Communication)}

Model aliran dua tahap ternyata tidak begitu efektif pada masyarakat yang tingkat buta hurufnya kecil. Masyarakat dengan kemampuan membaca dan mengintrepetasikan pesan yang di dengar dan di lihat sangat memungkinkan untuk menerima pesan-pesan dari media massa secara langsung. Meskipun itu tidak berarti mereka tidak menerima pesan-pesan dari opinion leader. Oleh karena itu untuk menyempurnakannya, muncullah model ali-ran banyak tahap (multi step flow model). Model ini mengatakan bahwa hubungan timbal balik dari media ke khalayak (yang juga berinteraksi satu sama lain), kembali ke media, kemudian kembali lagi ke khalayak dan seterusnya (Nuruddin, 2004:134).

Lewat model aliran banyak tahap ini, pemirsa menerima pesan-pesan media massa bisa langsung, bisa juga tidak langsung. Tidak langsung berarti mereka menerima pesan-pesan media melalui pe-mimpin opini atau kontak langsung dengan media massa. Bahkan individu bisa mendapatkan informasi dari individu yang lain. Misalnya, seorang individu menerima pesan melalui pemimpin opininya (setelah disebarkan lewat kelompok ), kemudian individu itu mencari informasi lain dari individu yang lain. Atau bisa juga seorang individu menerima pesan dari kelompoknya tetapi ia juga bisa mendapatkan informasi lain dari kelompok yang lain pula (Nuruddin, 2004:135).

Model ini menyatakan bahwa hubungan timbal balik dari media ke khalayak (yang juga berinteraksi satu sama lain), kembali ke media kemudian kembali lagi ke khalayak dan seterusnya. Lewat model ini audien dapat menerima pesan langsung dari media ataupun tidak, audiens bisa menerima pesan melalui media massa, melalui pemimpin opini ataupun melalui individu lain. Model ini menyatakan bahwa audience bisa memperoleh pesan secara langsung dari media massa ataupun dari sumber yang lain sebagai tangan kedua, ketiga dst. Model ini yang paling sedikit keterbatasannya bila dibanding model lain. Prinsipnya kita dipengaruhi dan memengaruhi orang lain.
Model ini lahir dengan pertimbangan bahwa dalam masyarakat terjadi proses sosial. Perspektif hubungan sosial inilah berpengaruh terhadap proses penyebaran pesan yang disampaikan media massa. Ada asumsi bahwa model ini merupakan model yang paling cocok karena menggabungkan beberapa hal dalam model komunikasi satu tahap dan dua tahap. Pada model pertama khalayak bersifat pasif, tapi ternyata khlayak aktif mencari informasi yang dia butuhkan dan menyampaikan kepada yang lain. Proses sosial ini menjadi salah satu yang melatarbelakangi lahirnya model komunikasi banyak tahap.

\section{Komunikasi dan Pesan}

Komunikasi merupakan suatu proses sosial yang sangat mendasar dan vital dalam kehidupan manusia. Dikatakan mendasar karena setiap masyarakat manusia, baik yang primitif maupun yang modern, berkeinginan mempertahankan suatu persetujuan mengenai berbagai aturan sosial melalui komunikasi. Dikatakan vital karena setiap individu memiliki kemampuan untuk berkomunikasi dengan individu individu lainnya sehingga meningkatkan kesempatan individu itu untuk tetap hidup (Rakhmat, 1998:1).

Kata komunikasi atau communication dalam bahasa Inggris berasl dari bahasa Latin communis yang berarti "sama", communico, communicatio, atau communicare yang berarti "membuat sama" (to make common). Istilah pertama (communis) adalah istilah yang paling sering sebagai asal usul komunikasi, yang merupakan akar dari kata-kata Latin lainnya yang mirip. Komunikasi menyarankan bahwa suatu pikiran, suatu makna, atau suatu pesan dianut secara sama (Mulyana, 2005 : 4).

Secara paradigmatis, komunikasi adalah proses penyampaian suatu pesan oleh seseorang kepada orang lain untuk memberi tahu atau mengubah sikap, pendapat, atau perilaku, baik langsung secara lisan maupun taklangsung melalui media (Effendy, 2006 : 5).

Dari pengertian diatas dapat dilihat bahwa komunikasi merupakan suatu proses penyampaian pesan yang dapat berupa pesan informasi, ide, emosi, keterampilan dan sebagainya melalui simbol atau lambang yang dapat menimbulkan efek berupa tingkah laku yang dilakukan dengan media-media tertentu

\section{Teori Sosial Kognitif}

Menurut Bandura (dalam Woolfolk, 2009) teori sosial kognitif adalah sebuah teori yang memberikan pemahaman, prediksi, dan perubahan perilaku manusia melalui interaksi antara manusia, perilaku, dan lingkungan. Teori ini didasarkan atas proposisi bahwa baik proses sosial maupun proses kognitif adalah sentral bagi pemahaman mengenai motivasi, emosi, dan tindakan manusia. Albert Bandura (dalam Santrock, 2010) mengatakan bahwa ketika murid belajar, mereka dapat merepresentasikan atau mentransformasikan pengalaman mereka secara kognitif.

Teori sosial kognitif digunakan untuk mengenal, memprediksi perilaku dan mengidentifikasi metodemetode yang tepat untuk mengubah perilaku tersebut. 
Teori ini menjelaskan bahwa dalam belajar, pengetahuan (knowledge), pengalaman pribadi (personal experience), dan karakteristik individu (personal characteristic) saling berinteraksi.

Social Cognitive Theory (teori kognitif sosial) adalah teori yang menambahkan faktor-faktor kognitif, seperti keyakinan, persepsi diri, dan ekspektasi pada teori pembelajaran sosial. Sedangkan determinisme resiprokal adalah penjelasan tentang prilaku yang menekankan efekefek mualistis antara individu dan lingkungan.

Dalam teori kognitif sosial, faktor-faktor internal maupun eksternal dianggap penting. Peristiwa di lingkungan, faktor-faktor personal, dan prilaku dilihat saling berinteraksi dalam proses belajar. Faktor-faktor personal (keyakinan, ekspektasi, sikap, dan pengetahuan), lingkungan fisik dan sosial (sumber daya, konsekuensi tindakan orang lain dan setting fisik) semuanya saling memengaruhi dan dipengaruhi. Banduran menyebutkan interaksi kekuatan-kekuatan ini Reciprocal determinism (determinisme resiprokal). Faktor-faktor sosial seperti model/panutan, strategi instruksional, atau umpan balik (elemen-elemen ling-kungan untuk siswa) dapat mempengaruhi faktor-faktor personal siswa, seperti tujuan, sense of efficacy untuk suatu tugas, atribusi (keyakinan tentang penyebab kesuksean dan kegagalan dan proses-proses regulasi diri, seperti merencanakan, memonitor/memantau dan mengontrol distraksi. Sebagai contoh umpan balik guru dapat membuat siswa menetapkan tujuan yang lebih tinggi. Pengaruh sosial dilingkungan dan faktor-faktor personal mendorong prilaku yang menghasilkan pencapaian seperti persistensi dan usaha motivasi dan pembelajaran.

\section{METODE}

Tipe penelitian ini adalah penelitian deskriptif dengan data kualitatif yang dilakukan dengan tujuan menggambarkan atau mendeskripsikan obyek dan fenomena yang berkaitan dengan faktor-faktor yang menyebabkan terjadinya perkawinan usia muda dikalangan remaja di masyarakat urban di Kabupaten Bandung. Karena penelitian ini mengkaji bagaimana kampanye komunikasi kesehatan melalui model multi step flow communication dalam menekan angka pernikahan usia dini pada masyarakat urban di kabupaten bandung maka, unit penelitiannya adalah para pendatang di daerah industri yang menikah di usia muda atau yang melakukan pernikahan usia dini. Unit populasi adalah seluruh masyarakat setempat yang tinggal di daerah Rancaekek. Pemilihan Rancaekek karena mrupakan wilayah industri memiliki banyak pabrik tekstil yang karyawannya sebagian besar pendatang dari luar daerah. Karena penelitian ini bersifat kualitatif maka penulis menggunakan sampel purposif yaitu tidak semua pendatang dianalisis tetapi pendatang yang menikah di usia dini.

Analisa data sekunder seperti data potensi desa dan Riskesdas dilakukan dengan pendekatan spasial. Pengumpulan data kualitatif dilakukan dengan cara observasi dan wawancara mendalam, informannya adalah para pasangan nikah usia dini di kabupaten Bandung.
Tujuan penelitian ini adalah memahami apa yang tersembunyi dibalik fenomena yang kadangkala merupakan sesuatu yang sulit untuk diketahui atau dipahami. Selain untuk memahami fenomena yang sulit dipahami, peneliti ingin menggali pengalaman individu dalam mendefinisikan suatu permasalahan dan masyarakat yang menjadi informan bebas mengungkapkan definisinya tersebut.

Instrumen yang yang digunakan untuk penelitian kualitatif adalah berupa kuesioner dengan pertanyaan terbuka dan panduan observasi. Panduan observasi meliputi setting yaitu dalam ruang lingkup rumah dan lingkungan pasngan nikah usia dini. Participant yaitu pasangan nikah usia dini. Aktivitas dan interaksi meliputi kegiatan sehari-hari dan frekuensi/durasi yaitu pola aktivitas (berapa kali dan berapa lama pengamatan dilakukan). Variabel yang diteliti yaitu karakteristik masyarakat seperti usia, pendidikan terahir dan status sosial ekonomi.

Pemilihan kabupaten kabupaten Bandung didasarkan pada banyaknya industri industri tekstil dan garmen yang didirikan di kabupaten Bandung mencakup wilayah majalaya, padalarang, dan Rancaekek. Dengan asumsi bahwa banyak pendatang dari desa mencari pekerjaan di wilayah wilayah tersebut dan menjadikan mereka menjadi masyarat urban. Mengapa dipilih masyarakat urban karena dengan asumsi pernikahan usia dini banyak dilakukan oleh masyarakat pedesaan yang datang merantau ke kota.

Metode pemilihan infomasi yang digunakan dalam penelitian ini adalah secara purposif. Sumber data yang digunakan disini tidak sebagai sumber data yang mewakili populasinya, tetapi mewakili informasi. Berdasar kepada akses tertentu yang dianggap memiliki informasi yang berkaitan dengan permasalahan secara mendalam dan dapat dipercaya sebagai sumber yang mantap.

\section{HASIL DAN PEMBAHASAN}

Pernikahan pada dasarnya sejalan dengan bertambahnya persoalan kependudukan, hal ini dikarenakan pernikahan berarti berkaitan dengan angka kelahiran. Oleh karena itu, pemerintah mem-berlakukan aturan-aturan pernikahan. Di-nyatakan dalam Undangundang perkawinan pasal 7 tahun 1974 ayat (1) perkawinan dapat dan dilakukan jika pihak laki-laki dan perempuan berusia minimal 19 tahun. Keluarnya undang-undang perkawinan pada dasarnya untuk mencegah adanya pernikahan dini, menurut kajian dari badan koordinasi dan keluarga bencana nasional yang sekarang menjadi badan kependudukan dan keluarga bencana nasional bahwa pernikahan dini berpotensi untuk mempercepat laju pertumbuhan penduduk. Disi lain, ada beberapa dampak negatif pernikahan dini, diantaranya :

1. Pernikahan dini berpotensi sulit mewujudkan pernikahan secara baik

2. Pernikahan dini memiliki potensi perceraian

3. Pernikahan dini memiliki resiko dalam memperoleh anak karena rahim ibu yang masih relatif muda 
4. Pernikahan dini berpotensi menambah masalah kependudukan

Namun demikian, dengan banyaknya per-masalahan yang dihadapi bagi pasangan usia muda tetp saja masih banyak terjadi penikahan dini di masyarakat. Hal ini dikarenakan adanya kebiasaan atau adat-istiadat pada masyarakat sekitar yang memiliki keyakinan bahwa menikah pada usia muda menunjukan bahwa mereka telah 'laku', sedangkan ketika berusia belum menikah dianggap tidak "laku" dan mendapat julukan perawan tua.

Pada dasarnya terdapat beberapa faktor kenapa banyak pasangan muda yang melangsungkan pernikahan di usia dini, diantaranya adalah pengaruh sosial dan budaya lingkungan tempat tinggalnya termasuk keluarga mereka sendiri yang menginspirasi terjadinya pernikahan sejak dini. Artinya bahwa orangtua juga memiliki peranan yang cukup dominan dalam keberlangsungan pernikahan di usia muda. Di sisi lain, agama juga menjadi alasan lain yang digunakan oleh pasangan usia muda, karena pasangan yang belum matang secara emosional ini berpikir bahwa menikah di usia muda dapat menghindari larangan-larang yang diatur dalam agama.

Realitas-realitas tersebut di atas semakin memperkuat peneliti untuk melakukan penelitian kampanye kesehatan yang dilakukan oleh badan kependudukan dan keluarga berencana nasioanal dalam menekan pernikahan dini. Adapun sebagai narasumber kami adalah masyarakat urban, yang notabene lebih mudah tertepa informasi yang diberikan oleh BKKBN melalui media. Penelitian ini bertujuan untuk mengetahui bagaimana karakteristik demografi pelaku pernikahan usia dini pada masyarakat urban, mengetahui faktor-faktor penyebab masyarakat urban melakukan pernikahan dini, mengetahui bagaimana gambaran personal determinans pelaku pernikahan usia dini, mengetahui bagaimana gambaran tanggapan pelaku pernikahan usia dini terhadap ILM pernikahan dini, mengetahui bagaimana gambaran peranan keluarga terhadap pelaku pernikahan dini.

\section{Karakteristik Demografis Pelaku Pernikahan Usia Dini}

Dari pendapat para ahli dapat disimpulkan bahwa demografi kependudukan memiliki arti yang sangat luas, dimana perubahan penduduk tidak hanya dilihat dari angka kelahiran dan kematian, melainkan dari adanya pergerakan-pergerakan sosial yang dilakukan oleh individu. Dalam hal ini menyangkut perubahan teritorial ataupun tempat tinggal individu tersebut. Berbasis pada pengertian demografi yang diungkapkan oleh para ahli, ditemukan beberapa faktor demografis pelaku penikahan dini diantaranya adalah pendidikan SMP dan SMA, Usia di saat menikah 15-20 tahun, kondisi ekonomi rumah tangga menengah ke bawah, dari keluarga yang memiliki anak banyak, dari keluarga yang orang tuanya juga menikah di usia dini, berasal dari wilayah pedesaan, merantau, tidak memiliki sanak keluarga di tempat perantauan, memiliki tingkat pencarian informasi yang rendah, memiliki tingkat ekposure pesan pesan kesehatan yang rendah, memiliki tingkat penyerapan informasi yang rendah.

\section{Pendidikan Pelaku Pernikahan Dini}

Pada dasarnya pelaku pernikahan ini adalah individu yang tidak memiliki jenjang pendidikan yang tinggi dari 25 narasumber yang peneliti wawancara, 20 narasumber menyatakan bahwa pada saatmelangsungkan pernikahan mereka baru saja menyelesaikan pendidikannya di level sekolah menengah atas (SMA), sisanya 5 narasumber baru saja menyelesaikan studinya di sekolah menengah pertama (SMP). Hal ini dikarenekan di level pedesaan pendidikan bukan menjadi hal yang utama, dimana pendidikan hanya sebagai pekerjaan sampingan. Umumnya mereka lebih banyak mengisi waktu luangnya untuk membantu orangtua di sawah maupun menjadi peternak. Bertani dan beternak bagi masyarakat usia muda di pedesaan adalah ilmu utama yang mereka peroleh.

\section{Usia Pada Saat Menikah}

Banyaknya dampak dari pernikahan dini tidak menyurutkan masyarakat khususnya masyarakat yang memiliki pengetahuan rendah untuk melangsungkan pernikahan dini. Hal ini dikarenaka adanya beberapa faktor, dari hasil wawancara dengan narasumber fakotfaktor yang melatarbelakangi mereka melakukan pernikahan dini adalah karena faktor ekonomi, faktor budaya, faktor agama dan faktor pendidikan.

Pada dasarnya ekonomi keluarga menjadi alasan utama bagi narasumber usntuk melangsungkan pernikahan dini, namun demikian masih adanya budaya di pedesaan yang mengganggap bahwa menikah di usian 16-19 tahun adalah sebuah keharusan untuk menjaga martabat mereka memicu angka pernikahan dini. Hal ini dikarenakan di pedesaan masih beranggapan bahwa menikah di atas 20 tahun membuat mereka tidak percaya diri.

Disisi lain pemahaman agama yang salah menjadi penyebab terjadinya pernikahan dini. Ada sebagai masyarakat kita yang memahami bahwa jika anak menjalin hubungan dengan lawan jenis, telah terjadi pelanggaran agama. Sebagai orang tua makan wajib melindungi dan mencegahnya dengan segerah menikahkan anak-anak tersebut. Hal ini lah yang menjadikan alasan narsumber melangsungkan pernikahan dini, orang tua mereka mendukung mereka menikah jika sudah punya pasangan, karena mereka tidak mau mendapatkan fitnah dari masyarakat. Mereka beranggapan bahwa jika anak mereka menjalin hubungan dengan lawan jenis, maka mereka sudah melakukan perzinahan.

Rendahnya pemahaman mereka terhadap agama, berkorelasi dengan tingkat pendidikan yang mereka miliki. Masyarakat yang melangsungkan pernikahan dini umumnya memiliki pendidikan rendah, hal ini dikarenakan ketika mereka putus sekolah, maka mereka mengisi waktu luang mereka dengan bekerja. Saatitulah sang anak akan merasa mampu mandiri cukup untuk memenuhi kebutuhannya. 


\section{Peranan Keluarga Terhadap Pelaku Pernikahan Usia Dini}

Keluarga merupakan pondasi bagi perkembangan anak, oleh karena itu pendidikan dalam keluarga hendaknya semakin dikuatkan kembali. Namun persoalannya adalah dalam kasus pernikahan dini, dari hasila wawancara dengan narasumber keluarga memiliki peranan untuk mendorong terjadinya pernikahan dini. Hal ini dikarenakan karena persoalan ekonomi, pemahaman agama yang rendah serta adanya budaya menikah di usia muda.

Namun demikian, pelaku pernikahan dini yang menjadi narasumber kami menyatakan bahwa setelah menikah mereka tidak lagi bergantung kepada kelurga untuk mencukupi kebutuhan sehari-hari. Mereka justru punya keingan untuk membantu orang tua di rumah, namun persoalannya mereka sendiri masih kekurangan untuk mencukupi kebutuhan sehari-hari, sehingga mereka hanya berbagi dengan orangtua pada saat lebaran saja. Realitas lain yang menjadi temuan peneliti adalah pelaku pernikahan dini selain dari keluarga tidak mampu juga berasal dari keluarga yang memiliki anak banyak, tingkat pendidikan rendah dan melakukan pernikahan dini juga.

Berdasarkan hasil penelitian, diketahui bahwa secara demografi, pelaku pernikahan dini memiliki beberapa karakteristik yang khas. Antara lain usia menikah yang dilakukan oleh para pelaku pernikahan dini berkisar antara 16-20 tahun. Secara prinsip usia tersebut sudah masuk kedalam rentang usia yang diperbolehkan oleh Undang-undang pernikahan. Namun demikian, berdasarkan pandangan dunia medis, usia tersebut merupakan usia yang masih dianggap rawan untuk melahirkan. Seperti yang terungkap dalam pernyataan berikut ini:

Riset para peneliti di Keck School of Medicine, University of Southern California (USC) mengindikasikan, perempuan yang melahirkan di bawah usia 25 tahun memiliki risiko besar mengidap kanker endometrium. Sebaliknya, perempuan yang melahirkan di atas usia 40 atau lebih mengalami penurunan risiko kanker endometrium sebesar 44 persen $^{2}$.

Berdasarkan pernyataan tersebut, maka diperlukan sosialisasi kepada masyarakat mengenai resiko yang dapat dialami oleh perempuan yang menikah dan hamil di usia dini, yaitu 25 tahun. Hal tersebut disebabkan karena selama ini, resiko terkena penyakit endometriosis karena melahirkan pada usia muda belum banyak diketahui masyarakat secara luas, hanya terbatas bagi masyarakat yang memiliki akses informasi yang komprehensif.

Selanjutnya, tingkat ekonomi pelaku pernikahan usia dini, berada dalam kelompok masyarakat ekonomi menengah ke bawah. Tingkat ekonomi ini lah yang sesungguhnya mempengaruhi keputusan masyarakat untuk menikah di usia muda. Karena pernikahan di usia dini lebih banyak dipengaruhi motif biologis untuk aspek keselamatan, yang meliputi kesehatan, keamanan perlindungan, ketentraman (Rakhmat, 2007: 301).

\footnotetext{
2 http://health.kompas.com/read/2012/07/26/13442769/Bahaya.Melahirkan.di.Usia. Muda.
}

Adapun faktor tingkat ekonomi juga mempengaruhi tingkt pendidikan dan terpaan informasi yang dimiliki oleh pelaku pernikhan dini. Hal ini disebabkan tingkat ekonomi yang rendah membuat masyarakat sulit untuk menempuh jenjang pendidikan tinggi, dengan adany tingkat pendidikan yang rendah, menyebabkan terpan informas pun menjadi terbatas karena akses terhadap media, lebih banyak digunakan untuk memperoleh hiburan dan bukan untuk mencari informasi, terlebih informasi kesehatan.

Faktor-faktor yang mendorong terjadinya pernikahan dini di kalangan masyarakat urban, dipengaruhi oleh faktor internal dan eksternal. Adapun untuk faktor internal lebih banyak dipengaruhi oleh rasa malu apabila telah menginjak usia tertentu namun belum menikah, terutama bagi kaum perempuan. Rasa malu ditimbulkan oleh konsep diri mereka yang lebih mengedepankan faktor afeksi daripada rasionalisasi pada saat mengambil keputusan.

Hal ini tidak mengherankan mengingat usia mereka masih muda untuk mengambil keputusan sepenting pernikahan. Karena usia 16-20 tahun adalah usia yang masuk ke dalam kategori remaja akhir atau belum memasuki usia dewasa yang berkisar 30-an, yang sudah dapat mengambil keputusan yang lebih baik guna menyelesaikan permasalahanpermasalahan hidup yang dialami seperti yang dinyatakan Hurlock bahwa: usia sekitar awal atau pertengahan tiga puluhan, kebanyakan orang muda juga telah mampu memecahkan masalah-masalah mereka dengan cukup baik sehingga menjadi stabil dan tenang secara emosional (Hurlock, 1999: 24).

Selain itu faktor personal determinant yang relatif masih tergolong belum stabil, mendorong pelaku untuk terpengaruh oleh himbauan, anjuran, bahkan paksaan pihak lain untk melakukan pernikahan dini, sekalipun seacra pribadi mereka pun belum siap untuk mengarungi kehidupan berumah tangga. Namun karena mereka belum mampu mengatasi desakan pihak luar maka mereka pun tetap mengambil keputusan untuk melakukan pernikahan dini walaupun mereka menyadari bahwa untuk melakukan sebuah pernikahan, mereka membutuhkan situasi untuk berada dalm kondisi ekonomi yang mapan.

Sesungguhnya dari aspek usia yang masih tergolong muda, dapat langsung diketahui bahwa usia pelaku pernikahan dini belum termasuk ke dalam golongan individu yang produktif secara ekonomi. Namun demikian dikarenakan sebagian besar pelaku sudah memiliki pekerjaan, maka mereka merasa mereka sudah memiliki penghasilan. Penghasilan yng dimiliki dapat menjadi penguat alasan untuk menikah karena merasa sudah produktif. Hal tersebut diperkuat oleh pernyataan Djaljoeni yang menyatakan bahwa: 1650 tahun termasuk ke dalam kelompok usia produktif (Djaljoeni, 1983: 38).

Berdasarkan faktor usia pula lah daya terpaan dan daya serap terhadap informasi pun menjadi rendah. Hal ini sesuai dengan pernyataan Wright bahwa: Individu berbed-beda dalam kecenderungan mereka terhadap isi pesan komunikasi dan bahwa perbedaan-perbedaan 
tersebut berhubungan dengan karakteristi sosial lainnya, termasuk tingkat pendidikan dan ekonomi (1989: 133).

Maka dari itu seberapa sering frekuensi penayangan dan durasi penayangan iklan layanan masarakat yang berisi tentang informasi kesehatan yang berkaitan dengan resiko menikah, hamil dan melahirkan di usia dini, tetap saja proses penyerapan informasinya menjadi terbatas sehingga informasi yang berkaitan dengan informasi kesehatan tersebut belum efektif.

Adapun faktor pengaruh sosial yang mempengaruhi masyrakat untuk memutuskan menikah di usia dini dikarenakan adanya pola kekerabatan yang sangat kuat di masyarakat yang menganut sistem budaya kolektif, sehingga hal-hal yang dianggap tabu oleh keluarga batih, keluarga besar, kerabat bahkan tetangga memiliki pengaruh dan peranan yang sangat kuat dalam pengambilan keputusan individu.

Hal ini meyebabkan, walaupun secara pribadi pelaku pernikahan usia dini belum ingin menikah namun mereka tidak sanggup untuk menolak desakan lingkungan untuk menikah. Hal ini disebabkan tingginya motif psikologis yang meliputi aspek kasih sayang yang mencakup faktor keluarga (Rakhmat, 2007: 301). Motif psikologis yang tinggi menyebabkan masyarakat tidak mampu untuk menolak keputusan bersama yang beresiko. Salah satu resiko yang ingin dihindari adalah resiko pengucilan oleh keluarga ataupun masyarakat secara sosial.

\section{DAFTAR PUSTAKA}

Departemen Kesehatan RI. 2006. Panduan, Pengelolaan Pusat Informasi dan Konseling Kesehatan Reproduksi Remaja (PIK-KRR). Jakarta: Direktorat Remaja dan Perlindungan Hak-hak Reproduksi

Hurlock B. Elizabeth. 1980. Psikologi Perkembangan. Jakarta: Erlangga
Fatchiah E. Kertamuda. Konseling Pernikahan Untuk Keluarga Indonesia. Salemba Humanika.

Juspin Landung, RidwanThaha', A. Zulkifli abdullah: Studi Kasus Kebiasaan Pernikahan Usia Dini Pada Masyarakat Kecamatan Sanggalangi Kabupaten Tana Toraja. Jurnal MKMI, Vol 5 No.4. Oktober 2009, hal 89-94

M. Idris Ramulyo, Beberapa Masalah Tentang Hukum Acara Peradilan Agama Dan Perkawinan Islam, (Jakarta : Hill.Co, 1984)

McQuail, Denis.1991. Teori Komunikasi Massa: Suatu Pengantar.

Diterjemahkan Aminuddin Ram. Jakarta : Erlangga.

Ormrod, Jeanne E. 2006. Educational Psychology: Developing Learners 5th Edition. Ohio: Pearson

Rakhmat, Jalaluddin. 2007 Psikologi Komunikasi. Bandung: Remaja Rosdakarya.

Siti Yulia Astuti. "Faktor-faktor yang Menyebabkan Terjadinya Perkawinan Usia Muda Dikalangan Remaja di Desa Tembung Kecamatan Percut Sei Tuan Kabupaten Deli Serdang”. Skripsi

Santrock, John W. 2010. Psikologi Pendidikan (Edisi Kedua). Jakarta: Kencana

Suparman. Eman 2001. Upaya Mencegah Kebiasaan Kawin Muda Di Kalangan Remaja Di Pedesaan.

Mulyana, Deddy. 2005. Ilmu Komunikasi Suatu Pengatar. Rosdakarya. Bandung

Woolfolk, Anita. 2004. Educational Psychology (Ninth Edition). Boston: Allyn and Bacon

Woolfolk, Anita. 2009. Educational Psychology: Active Learning Edition (Edisi Sepuluh). Yogyakarta : Pustaka Pelajar 